\title{
A Simple Approach to Integrate the Ecotoxicological and Chemical Data for the Establishment of Environmental Risk Levels
}

\author{
Augusto Cesar ${ }^{1,2_{*}}$, Denis Moledo de Souza Abessa ${ }^{3}$, Camilo Dias Seabra Pereira ${ }^{2,4}$, Aldo \\ Ramos Santos $^{2}$, Nuria Fernández ${ }^{1}$, Rodrigo Brasil Choueri ${ }^{1}$ and Tomas Angel DelValls ${ }^{1}$ \\ ${ }^{I}$ Department of Physical Chemistry; Faculty of Marine and Environmental Sciences; University of Cádiz; C.P.: \\ 11510; Puerto Real - Cádiz - Spain. ${ }^{2}$ Departamento de Ecotoxicologia; Universidade Santa Cecília; Rua Oswaldo \\ Cruz, 266; 11045-907; Santos - SP - Brasil. ${ }^{3}$ Campus Experimental do Litoral Paulista; Universidade Estadual \\ Paulista; Praça Infante Dom Henrique, s/n; 11330-900; São Vicente - SP - Brasil. ${ }^{4}$ Instituto Oceanográfico da \\ Universidade de São Paulo; Praça do Oceanográfico, 191; São Paulo - SP - Brasil
}

\begin{abstract}
In this work, multivariate and numeric methods were used to integrate the chemical and ecotoxicological data obtained for the sediments from the Santos Estuarine System, and for the vicinity of the discharges of the Submarine Sewage Outfall of Santos, in order to establish more accurately the environmental risks, identify the priority areas and thus provide guidance to control the programs and public policies. For both the datasets, the concentrations which exceeded numeric sediment guidelines tended to be associated to toxicity. For the estuary, this trend was corroborated by the correlations between the toxicity and $\mathrm{Cu}$ and PAHs levels, whereas for the sewage outfall region, this was observed through the correlation between the toxicity and $\mathrm{Hg}$ contents. Ratio-to-mean values were calculated for each sample, in order to rank them according to the toxicity and contamination. Cluster analyses confirmed the ranking results. For the estuary, three categories of sediments were established: stations SSV-2, SSV3 and SSV-4 were under major risks, followed by SSV-6. Stations SSV-1 and SSV-5 were not altered. Concerning to the sewage outfall, stations 1 and 2 presented better quality, whereas station 5 seemed to be under risk, followed by stations 3 and 4 , which exhibited some signs of alteration.
\end{abstract}

Key words: Sediment, Contamination, Toxicity, Tiburonella viscana, Environmental risk assessment

\section{INTRODUCTION}

The Santos Estuarine System (SES) is located on the coast of the State of São Paulo, Brazil and comprises part of the Baixada Santista Metropolitan Region. The biggest Brazilian industrial complex as well as the major Latin
American port, the port of Santos, are in this densely urbanized region. Apart from the distinct economical significance, the region has also noticeable environmental importance since Santos and São Vicente Estuarine System are surrounded by the mangroves, which correspond to $43 \%$ of

* Author for correspondence: aucesar@unisanta.br 
total mangrove area of São Paulo (Lamparelli et al., 2001).

The quality of the sediments from SES has been studied already, with the purpose of environmental diagnosing and monitoring (Abessa, 2002; Abessa et al., 1998; 2001; 2005; Lamparelli et al., 2001; Prósperi, 2002; Rachid, 2002; Cesar et al., 2006). However, only a few of these authors attempted to integrate the data of different natures in a comprehensive approach. Such approach is needed for a better decision-making process and also to the establishment of public policies, aiming to protect the natural resources, or mitigate the environmental impacts.

Therefore, the objective of this study was to use some simple methods to integrate the ecotoxicological and chemical data, in order to obtain the environmental risk levels, which could support further actions, particularly the remediation of contaminated sites.

\section{MATERIALS AND METHODS}

This study used the ecotoxicological and chemical data obtained by Cesar et al. (2006) for the sediment samples collected in different areas along the SES, and the data produced by Abessa et al. (2005) for the vicinity of the Submarine Sewage Outfall of Santos (SSOS), also situated in the SES (Fig.1).
The first dataset comprised the samples from six sites, with different degrees of degradation. Three sampling sites were located in the Santos Channel, in the zone influenced by the harbor and industrial zone (SSV-1 to SSV-3); two sampling sites were located in the São Vicente Channel (SSV-4 and SSV-5), which was mainly influenced by the discharges of untreated sewage and by irregular domestic and industrial landfills; and the last site was located in the central portion of Santos Bay (SSV-6), near the SSOS.

The grain size distribution expressed as \% fines $(<63 \mu \mathrm{m})$, total organic carbon (TOC) and concentrations of $\mathrm{Zn}, \mathrm{Cd}, \mathrm{Pb}, \mathrm{Cu}, \mathrm{Ni}, \mathrm{Co}, \mathrm{V}$, total PAHs and total PCBs were determined by using the appropriate methods, according to the specialized scientific literature (USEPA 8080, 8310, 1999; APHA, 1999). The whole-sediment toxicity test with the amphipod Tiburonella viscana was conducted following the standard protocol (Abessa and Sousa, 2003; Melo and Abessa, 2002).

For the second dataset used in the present work, the sediments were collected at five stations distributed around the SSOS diffusers. These sediments were analyzed for the grain size distribution, total organic carbon (TOC), Al, Fe, $\mathrm{Cd}, \mathrm{Cr}, \mathrm{Co}, \mathrm{Hg}, \mathrm{Ni}, \mathrm{Pb}$ and $\mathrm{Zn}$ concentrations and Methylene Blue Active Substances (MBAS), i.e. anionic detergents. The toxicity test was conducted with the same amphipod species $T$. viscana.

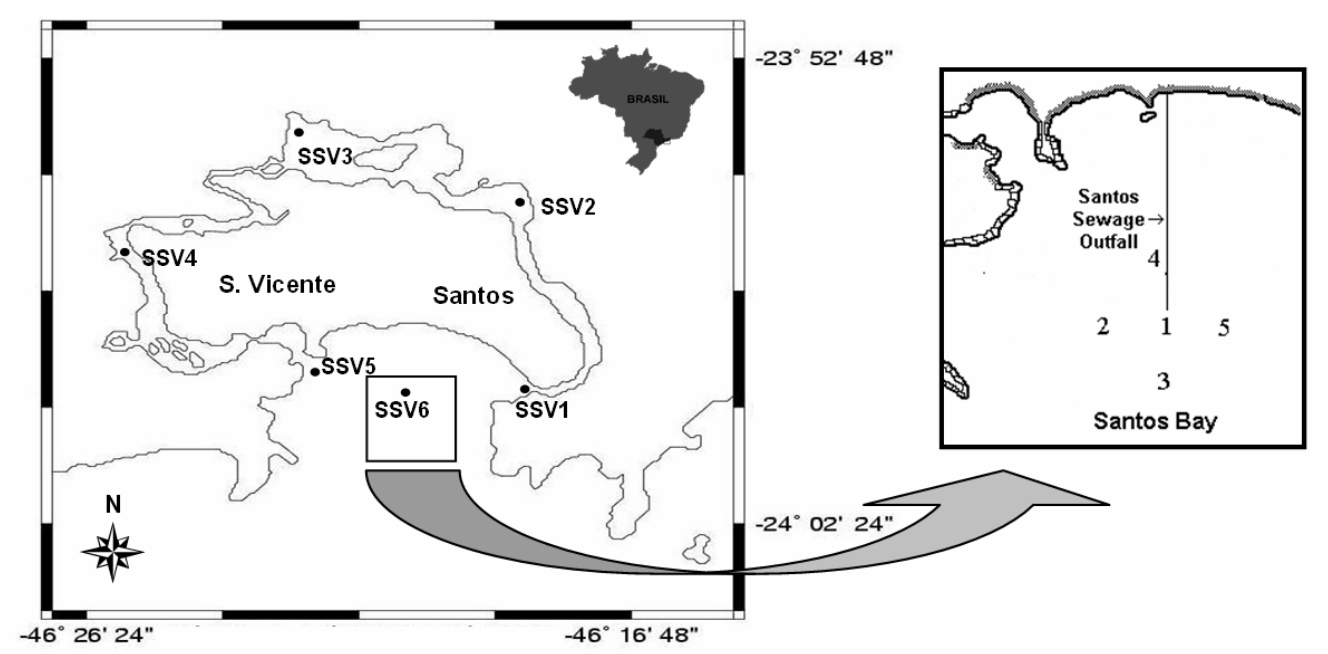

Figure 1 - Geographical location and position of the sampling points in the Santos and São Vicente estuarine system. In the detail, the sampling stations around the SSOS are showed. 
For both the dataset, the chemistry data were firstly compared to the Canadian Sediment Quality Guidelines (Smith et al., 1996), in order to analyse the single risk of each contaminant to benthic organisms. The presence of acute toxicity (i.e., significant amphipod mortality) was also interpreted as an evidence of risk to the environment.

Thereafter, the data were combined by using the multiple linear correlations. This method was applied to observe linear associations between the contaminants/toxicity and some sediment properties (organic carbon and grain size distribution), and also between the toxicity and contamination.

Furthermore, a cluster analysis was conducted with each data set (Bray Curtis distance; Group Average Link), in order to separate the sediments with different degrees of quality for the aquatic life. To better understand such differences, a method was used to rank the six sediment samples, according to their environmental quality.

This method was adapted from the Ratio to Maximum Value approach (Del Valls and Chapman, 1998; Del Valls et al., 1998), normally used for the sediment quality triad, with some modifications proposed by Abessa (2002) to the SES, and consisted of four steps explained below.

Step 1 consisted of the calculation of mean values for each contaminant and toxicity, based on the values obtained for each of the six stations. In the Step 2, ratio-to-mean values were established (RTMe) by dividing the value for each sediment sample by the respective calculated mean. This provided a new matrix, containing the RTMe values for each variable. In Step 3, an arithmetic mean for the contaminants was calculated, providing a mean RTMe for the all the considered chemicals at each station. Step 4 consisted of calculating an arithmetic mean of the RTMe values obtained for the toxicity and contaminants. Thus, the data could be reduced to a single value for each sample, which could be used to rank the sediments and consequently, the sampling sites, based on the environmental quality.

\section{RESULTS AND DISCUSSION}

\section{Santos Estuarine System}

The results obtained by Cesar et al. (2006) for the sediment contamination and physical-chemical parameters are summarized in the Table 1 . Sediment samples tended to present low percents of fines, except those from SSV-3 and SSV-6, which presented slightly higher contents. The Organic Carbon (OC) levels in the sediments tended to be low. The higher OC levels were found in the sediments collected in the inner estuary. Regarding the chemical contamination, concentrations above the Canadian "Threshold Effect Level" (TEL) were found for $\mathrm{Cu}$ (SSV-2; SSV-3; SSV-4); V (SSV-3 and SSV-4); Zn (SSV2) and Total PAHs (SSV-2; SSV-3; SSV-4; SSV6). Significant toxicity was observed in the sediments from stations (SSV-2; SSV-3; SSV-4; SSV-5 and SSV-6). Therefore, sites SSV-2, SSV3 , SSV-4 and SSV-6 exhibited both the chemical and ecotoxicological evidences of degradation. Abessa (2002) found that the most of toxic sediments in the SES exhibited contamination above the TEL. For the station SSV-5, there was only an ecotoxicological evidence of degradation, which could be caused by a non-measured contaminant or by a natural factor. Sediments from SSV-1 did not exhibit chemical contamination above the TEL or amphipod toxicity.

Table 1 - Results of amphipod toxicity test and physical-chemical analyses in the sediments from Santos and São Vicente Estuary (from Cesar et al., 2006).

\begin{tabular}{|c|c|c|c|c|c|c|c|c|c|c|c|c|}
\hline \multirow{2}{*}{$\begin{array}{l}\text { Sampling } \\
\text { sites }\end{array}$} & \multirow{2}{*}{$\begin{array}{c}\begin{array}{c}\text { Amphipod } \\
\text { mortality }(\%)\end{array} \\
\text { Mean } \pm \text { sd }\end{array}$} & \multicolumn{7}{|c|}{ Metals (mg.kg ${ }^{-1}$ ) } & \multicolumn{2}{|c|}{ Organics } & \multicolumn{2}{|c|}{$\begin{array}{l}\text { Sediment } \\
\text { properties }\end{array}$} \\
\hline & & Cd & Co & $\mathrm{Cu}$ & $\mathbf{N i}$ & $\mathbf{P b}$ & $\mathbf{V}$ & Zn & 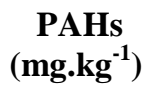 & $\begin{array}{c}\text { PCBs } \\
\left(\mu \mathrm{g} \cdot \mathrm{kg}^{-1}\right)\end{array}$ & $\begin{array}{l}\text { OC } \\
(\%)\end{array}$ & $\begin{array}{c}\text { Fines } \\
(\%)\end{array}$ \\
\hline SSV-1 & 25.0 & $<0.1$ & $<0.1$ & $<0.1$ & 4.85 & 17.4 & 36.0 & 73.3 & 0.106 & 0.66 & 3.75 & 3.96 \\
\hline SSV-2 & $72.5 \pm 2.5$ & $<0.1$ & $<0.1$ & 167.2 & 2.96 & 66.2 & 24.0 & 154.2 & 0.518 & 4.00 & 1.24 & 4.46 \\
\hline SSV-3 & $77.5 \pm 6.3$ & $<0.1$ & $<0.1$ & 157.7 & 4.49 & 22.1 & 87.8 & 110.4 & 0.425 & 2.61 & 2.78 & 9.68 \\
\hline SSV-4 & $80.0 \pm 5.8$ & $<0.1$ & $<0.1$ & 69.0 & 3.83 & 14.9 & 104.8 & 66.8 & 0.950 & 0.94 & 2.82 & 2.67 \\
\hline SSV-5 & $40.0 \pm 4.1$ & $<0.1$ & $<0.1$ & $<0.1$ & 3.89 & 8.69 & 18.6 & 32.6 & 0.163 & 0.58 & 0.85 & 1.42 \\
\hline SSV-6 & $67.5 \pm 4.8$ & $<0.1$ & $<0.2$ & $<0.1$ & 6.02 & 14.6 & $<0.1$ & 53.2 & 0.600 & $<0.1$ & 1.00 & 11.56 \\
\hline
\end{tabular}


The correlation analyses $(p<0.05)$ showed that the $\mathrm{V}$ concentrations were associated to the OC $(\mathrm{r}=$ 0.63), whereas nickel presented positive correlation to the percent of fines $(r=0.69)$. The amphipod mortality showed positive correlation to PAHs $(\mathrm{r}=0.84)$ and $\mathrm{Cu}(\mathrm{r}=0.68)$. Weak correlations were observed between the toxicity and V ( $\mathrm{r}=0.47), \mathrm{Zn}(0.44)$, and total PCBs ( $\mathrm{r}=$ $0.45)$. The results of these analyses showed that those contaminants which exceeded TEL values were strongly associated to amphipod toxicity, corroborating the results provided by the single occurrence of toxicity and/or TEL exceedance. Besides the appropriate characterization of the ecological risks, their origin and possible effects, a proper environmental management in SES would require the establishment of priority areas in which some intervention would be needed. Thus, ranking the six study sites became necessary, which was done by the RTMe method (Table 2). The position of each sample in this ranking was relative only to the set of data being analysed, were the ranking showed the quality of each sample in relation to the others, and among them, indicating which ones were in better and worse conditions. This ranking couldnot be used with any other purpose, especially in comparisons to external data.

Table 2. Ratio to Mean Values (RTMe) calculated for each contaminant, for the toxicity and their combination into Site-Specific values for the Santos Estuarine System.

\begin{tabular}{|c|c|c|c|c|c|c|c|c|c|c|}
\hline \multirow{3}{*}{$\begin{array}{l}\text { Sampling } \\
\text { Sites }\end{array}$} & \multicolumn{9}{|c|}{ Ratio to Mean Values (RTMe) } & \multirow{3}{*}{$\begin{array}{l}\text { Site-Specific } \\
\text { RTMe }\end{array}$} \\
\hline & \multicolumn{8}{|c|}{ Chemistry } & \multirow{2}{*}{$\begin{array}{c}\text { Toxicity } \\
\text { Amphipod mortality }\end{array}$} & \\
\hline & $\mathbf{C u}$ & $\mathbf{N i}$ & $\mathbf{P b}$ & $\mathbf{V}$ & $\mathbf{Z n}$ & PAHs & PCBs & Mean & & \\
\hline SSV-1 & 0.00 & 1.12 & 0.73 & 0.80 & 0.90 & 0.23 & 0.45 & 0.60 & 0.41 & 0.51 \\
\hline SSV-2 & 2.54 & 0.68 & 2.76 & 0.53 & 1.89 & 1.13 & 2.70 & 1.75 & 1.20 & 1.47 \\
\hline SSV-3 & 2.40 & 1.03 & 0.92 & 1.94 & 1.35 & 0.92 & 1.76 & 1.48 & 1.28 & 1.38 \\
\hline SSV-4 & 1.05 & 0.88 & 0.62 & 2.32 & 0.82 & 2.07 & 0.64 & 1.20 & 1.32 & 1.26 \\
\hline SSV-5 & 0.00 & 0.90 & 0.36 & 0.41 & 0.40 & 0.35 & 0.39 & 0.40 & 0.66 & 0.53 \\
\hline SSV-6 & 0.00 & 1.39 & 0.61 & 0.00 & 0.65 & 1.30 & 0.07 & 0.57 & 1.12 & 0.85 \\
\hline
\end{tabular}

According to the ranking, stations SSV-1 and SSV-5 presented the lower RTMe values. These two areas seemed to be not degraded. However, sediments from SSV-5 exhibited toxicity. Since no significant contamination was measured in this station, further studies were required to confirm the toxicity. Stations SSV-2, SSV-3 and SSV-4 had the highest RTMe values, indicating that these three stations were the most degraded among the studied sites. The sediments on such stations presented the toxicity and the concentration of three contaminants exceeded their corresponding TEL values. Station SSV-6 exhibited an intermediate RTMe value, which was due to the toxicity and to PAHs concentration which exceeded TEL value.

The result produced by the RTMe method was confirmed by the cluster analysis (Fig. 2). Stations SSV-2, SSV-3 and SSV-4 were grouped together, whereas stations SSV-1 and SSV-5 formed another group. Station SSV-6 placed between these two groups, showing intermediate signs of degradation.

This new interpretation confirmed the findings presented by Cesar et al. (2006) that the toxicity was closely related to the contamination, and the sediments from the internal portions of the SES were degraded. Moreover, the methods used to interpret the data in a risk-based view showed that stations SSV-2, SSV-3 and SSV-4 were under major risks and could be considered as priority for the establishment of control and remediation programs. Station SSV-6, situated close to the SSOS, also exhibited signs of being under environmental risk, showing that control programs should be implemented for the SSOS. Stations SSV-1 and SSV-5 did not seem to be at risk, although further studies could be recommended for SSV-5, since the sediments were acutely toxic to $T$. viscana. 


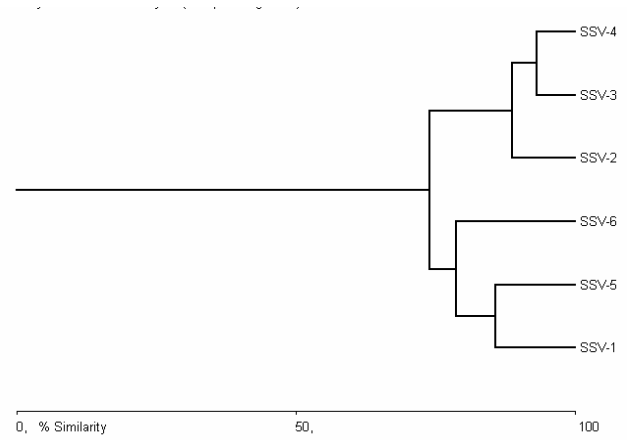

Figure 2 - Cluster analysis result using chemical and ecotoxicological data obtained by Cesar et al. (2006) for the Santos Estuarine System (Bray Curtis distance; Group Average Link).

\section{Submarine Sewage Outfall of Santos}

The original results for sediment contamination and physical-chemical parameters are show in the Table 3 (Abessa et al., 2005). Sediments from stations 1, 2 and 4 were composed primarily of sand, whereas those from stations 3 and 5 were sandy muds. The highest TOC levels were measured in the sediments of stations 2 and 5, respectively.

The levels of metals tended to be low in most of the samples. However, concentrations higher than TEL values were observed for $\mathrm{Hg}$ in stations 4 and 5 and $\mathrm{Ni}$ in station 5 . The highest concentrations of all the metals occurred in station 5, although mostly below the TEL. The highest anionic detergent (MBAS) contents were observed in the sediments from stations 1 and 2 , but it did not cause amphipod toxicity, confirming that measured MBAS levels were moderate in the region. Significant toxicity was observed in the sediments from stations 3 and 4, when compared to the negative control.

Therefore, station 4 presented the chemical and ecotoxicological evidences of degradation, and station 3 presented the ecotoxicological evidences of degradation. However, Abessa et al. (2005) reported high levels of unionized ammonia in the porewater extracted from these sediments, close to the LC50-72h values to this species, which were 1.83 (0.87-3.84) mg.L $\mathrm{L}^{-1} \mathrm{NH}_{3}$ (Abessa, 2002). Thus, this compound could have influenced the results. Station 5 exhibited some contaminants above TEL, but no acute toxicity, and sediments from stations 1 and 2 were considered of low contamination by Abessa et al. (2005).

The mud content correlated with the concentrations of $\mathrm{Cd}(\mathrm{r}=0.70)$ and $\mathrm{Cr}(\mathrm{r}=0.64)$. The TOC percent also correlated with these two metals $(0.64$ and 0.55 , respectively).

Table 3. - Results of amphipod toxicity test and physical-chemical analyses in the sediments collected close to the Submarine Sewage Outfall of Santos (from Abessa et al., 2005).

\begin{tabular}{|c|c|c|c|c|c|c|c|c|c|c|c|c|c|}
\hline \multirow{2}{*}{$\begin{array}{l}\text { Sampling } \\
\text { sites }\end{array}$} & \multirow{2}{*}{$\begin{array}{c}\begin{array}{c}\text { Amphipod } \\
\text { mortality }(\%)\end{array} \\
\text { Mean } \pm \text { sd }\end{array}$} & \multicolumn{2}{|c|}{ Metals (\%) } & \multicolumn{7}{|c|}{ Metals (mg.kg $\left.{ }^{-1}\right)$} & \multicolumn{2}{|c|}{$\begin{array}{l}\text { Sediment } \\
\text { properties }\end{array}$} & \multirow{2}{*}{$\begin{array}{r}\text { MBAS } \\
-\left(\mathbf{m g} . \mathbf{k g}^{1}\right)\end{array}$} \\
\hline & & Al & $\mathbf{F e}$ & n & $\mathbf{N i}$ & $\mathbf{P}$ & C & $\mathrm{Cr}$ & Co & $\mathrm{Hg}$ & $\begin{array}{c}\text { TOC } \\
(\%)\end{array}$ & $\begin{array}{c}\text { Fines } \\
(\%)\end{array}$ & \\
\hline 1 & $16.3 \pm$ & 399 & 1.78 & 50.63 & 2.51 & 12 . & .5 & 14. & 5.80 & 0.09 & 1.01 & 27.67 & 7.33 \\
\hline 2 & & & 1.78 & 42.84 & 11.40 & 11.3 & $<$ & & 5.15 & 0.09 & 1.73 & 8.88 & \\
\hline 3 & & & 2.02 & 44.59 & 12.39 & 8. & & & 5.40 & 0.05 & 0.91 & 55.69 & \\
\hline 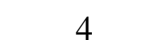 & & & & 51 & 14 & 16 & $<1$ & & 5.61 & 0.05 & 0.96 & 3.91 & 4. \\
\hline  & & & 3.2 & 65. & 20.91 & 25 . & 0.6 & & 11.15 & 0.17 & 1.53 & 67.39 & 4.89 \\
\hline Control & $0 \pm 4.5$ & 7.14 & 3.20 & 78.97 & 17.37 & 14.74 & 0.5 & 22.03 & 12.86 & 0.03 & 1.87 & 3.69 & 4.40 \\
\hline
\end{tabular}


A positive correlation was observed between the amphipod mortality and $\mathrm{Hg}(\mathrm{r}=0.82)$, suggesting that was one of the causes of the observed toxicity. Moreover, negative correlations were observed for $\mathrm{Al}(\mathrm{r}=-0.70), \mathrm{Zn}(\mathrm{r}=-0.59), \mathrm{Co}(\mathrm{r}=-0.59)$ and TOC $(r=-0.84)$ levels, indicating that probably there was an association between the fines and TOC with some metals.
The ranking of sample based on the RTMe method (Table 4) showed better sediment quality in stations 1 and 2. Alteration in sediment quality was observed for stations 3,4 and 5, which were situated at South, North and East of the SSOS diffusers. The highest RTMe value was obtained for Station 5.

Table 4 - Ratio to Mean Values (RTMe) calculated for each contaminant, toxicity and their combination into SiteSpecific values for the Submarine Sewage Outfall of Santos.

\begin{tabular}{|c|c|c|c|c|c|c|c|c|c|c|c|c|c|}
\hline \multirow{3}{*}{$\begin{array}{l}\text { Sampling } \\
\text { Sites }\end{array}$} & \multicolumn{12}{|c|}{ Ratio to Mean Values (RTMe) } & \multirow{3}{*}{$\begin{array}{c}\text { Site- } \\
\text { Specific } \\
\text { RTMe }\end{array}$} \\
\hline & \multicolumn{11}{|c|}{ Chemistry } & \multirow{2}{*}{$\begin{array}{c}\text { Toxicity } \\
\begin{array}{c}\text { Amphipod } \\
\text { mortality }\end{array}\end{array}$} & \\
\hline & Al & $\mathrm{Fe}$ & Zn & $\mathbf{N i}$ & $\mathbf{P b}$ & Cd & $\mathrm{Cr}$ & Co & $\mathrm{Hg}$ & MBAS & Mean & & \\
\hline 1 & 0.92 & 0.81 & 0.99 & 0.87 & 0.82 & 0.94 & 0.77 & 0.76 & 0.96 & 1.32 & 0.92 & 0.82 & 0.87 \\
\hline 2 & 0.91 & 0.81 & 0.84 & 0.87 & 0.76 & 0.94 & 0.29 & 0.68 & 1.01 & 1.14 & 0.82 & 0.71 & 0.77 \\
\hline 3 & 1.00 & 0.92 & 0.87 & 0.87 & 0.60 & 0.94 & 0.97 & 0.71 & 0.55 & 0.87 & 0.83 & 1.42 & 1.13 \\
\hline 4 & 0.97 & 0.99 & 1.01 & 0.87 & 1.09 & 0.94 & 0.92 & 0.74 & 0.58 & 0.79 & 0.89 & 1.60 & 1.25 \\
\hline 5 & 1.21 & 1.48 & 1.29 & 0.87 & 1.73 & 1.22 & 2.05 & 1.46 & 1.90 & 0.88 & 1.41 & 1.19 & 1.30 \\
\hline
\end{tabular}

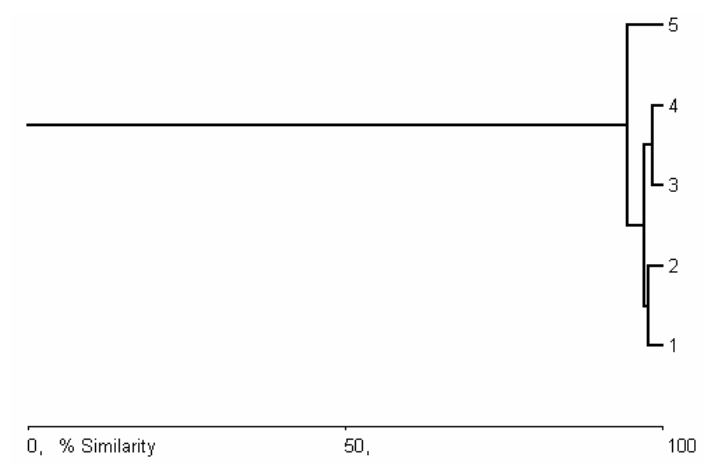

Figure 3. - Cluster analysis result using chemical and ecotoxicological data obtained by Abessa et al. (2005) for the vicinity of the Submarine Sewage Outfall of (Bray Curtis distance; Group Average Link).

As mentioned by Abessa et al. (2005), the result for station 1 was unexpected, since this station was located very close to the SSOS diffusers. This could be explained by the sediment transport towards the east (i.e., towards the Station 5), that occurred after the passage of low-pressure systems. Stations 3 and 4 were under the influence of the effluent plume in normal weather conditions (Harari et al., 1997; 2000), which could help to explain the $\mathrm{Hg}$ contamination in the sediments from station 4 and the toxicity in both the sediments.

The ranking was confirmed and even more detailed by the cluster analysis (Fig. 2). This method grouped the sediments from the stations 1 and 2 together, which could be classified as low or not degraded. A second group was formed by the stations 3 and 4, which presented few evidences of degradation. In this analysis, station 5 was placed isolated from the others stations; this sediment sample showed more evidences of degradation and could be classified as moderately degraded.

Those results showed that both specific sediment quality values and multivariate analyses could improve the integrated interpretation of the ecotoxicological and chemical data based in the 
weight of evidences, providing a rapid, easy and effective identification of "hot spots" from an intensive set of data in the environmental quality studies.

\section{ACKNOWLEDGEMENTS}

This work was partially funded by the BrazilianSpanish joint project (CAPES-Brazil \#099/06 BEX 3239/06-3; BEX 3238/06-07, MEC- Spain PHB2005-0100-PC and Spanish Ministry of Education Project CTM2005- 07282-C03C01/ TECNO - UNITWIN/UNESCO/WiCop). Denis

Abessa would like to thank FAPESP (98/00808-6) for the financial support.

\section{RESUMO}

O presente trabalho utilizou métodos multivariados e matemáticos para integrar dados químicos e ecotoxicológicos obtidos para o Sistema Estuarino de Santos e para a região próxima à zona de lançamento do emissário submarino de Santos, com a finalidade de estabelecer com maior exatidão os riscos ambientais, e assim identificar áreas prioritárias e orientar programas de controle e políticas públicas. Para ambos os conjuntos de dados, as violações de valores numéricos de qualidade de sedimento tenderam a estar associadas com a ocorrência de toxicidade. Para o estuário, essa tendência foi corroborada pelas correlações entre a toxicidade e as concentrações de HPAs e $\mathrm{Cu}$, enquanto para a região do emissário, pela correlação entre toxicidade e conteúdo de mercúrio no sedimento. Valores normalizados em relação às medias foram calculados para cada amostra, permitindo classificá-las de acordo com a toxicidade e a contaminação. As análises de agrupamento confirmaram os resultados das classificações. Para os dados de sistema estuarino, houve a separação das amostras em três categorias: as estações SSV2, SSV-3 e SSV-4 encontram-se sob maior risco, seguidas da estação SSV-6. As estações SSV-1 e SSV-5 demonstraram melhores condições. Já em relação ao emissário, as amostras 1 e 2 apresentaram melhores condições, enquanto a estação 5 pareceu apresentar um maior risco, seguida das estações 3 e 4 que tiveram apenas alguns indícios de alteração.

\section{REFERENCES}

Abessa, D. M. S. (2002), Avaliação da Qualidade de Sedimentos do Sistema Estuarino de Santos. SP. Brasil. Doctorate Thesis. Universidade de São Paulo. Instituto Oceanográfico. São Paulo. 290p.

Abessa, D. M. S. and Sousa, E. C. P. M. (2003), Sensitivity of the amphipod Tiburonella viscana to $\mathrm{K}_{2} \mathrm{Cr}_{2} \mathrm{O}_{7}$. Brazilian Arch. Biol. Technol., 46(1), 3-55.

Abessa, D. M. S.; Sousa, E. C. P. M.; Rachid, B. R. F. and Mastroti, R. R. (1998), Use of the burrowing amphipod Tiburonella viscana as a tool in marine sediments contamination assessment. Brazilian Arch. Biol. Technol., 41(2), 225-230.

Abessa, D. M. S.; Sousa, E. C. P. M.; Rachid, B. R. F. and Mastroti, R. R. (2001), Sediment toxicity in Santos estuary. SP-Brazil: preliminary results. Ecotoxicology Environ. Restaur., 4(1), 6-9.

Abessa, D. M. S.; Carr, R. S.; Rachid, B. R. F.; Sousa, E. C. P. M.; Hortelani. M. A. and Sarkis. J. E. (2005), Influence of a Brazilian Sewage Outfall on the Toxicity and Contamination of Adjacent Sediments. Marine Poll. Bull., 50, 875-885.

American Public Health Association (1999), AWWA/WPCF, Standard Methods for the Examination of Water and Wastewater, 20th ed, Washington, DC.

Cesar, A.; Pereira, C. D. S.; Santos, A. R.; Abessa, D. M. S.; Fernández, N.; Choueri, R.; DelValls, A. (2006), Ecotoxicology assessment of sediments from Santos and São Vicente Estuarine System - Brazil. Brazilian Jour. Ocean., 54 (1), 55-63

DelValls, T. A.; Chapman, P. M. (1998), Site-specific quality values for the gulf of Cádiz (Spain) and San Francisco Bay (USA). using the sediment quality triad and multivariate analysis. Ciencias Mar., 24(3), 313-336.

DelValls, T. A.; Forja. J. M.; Gómez-Parra. A. (1998), The use of multivariate analysis to link sediment contamination and toxicity data to establish sediment quality guidelines: an example in the Gulf of Cádiz (Spain). Ciencias Mar., 24(2), 127-154.

Harari, J.; Camargo, R. (1997), Simulações da circulação de maré na região costeira de Santos (SP) com modelo numérico hidrodinâmico. Pesquisas Nav., 10, 173-188.

Harari, J. Camargo, R.; Cacciari, P.L. (2000), Resultados da modelagem numérica hidrodinâmica em simulações tridimensionais das correntes de maré na Baixada Santista. Revista Brás. Rec. Hídr., 5(2), 71-87.

Lamparelli, M. L.; Costa, M.P.; Prósperi, V. A.; Bevilácqua, J. E.; Araújo, R. P. A.; Eysink, G. G. L. and Pompéia, S. (2001), Sistema Estuarino de Santos $e$ São Vicente. Relatório Técnico CETESB. São Paulo. 178 p. 
Melo, S. L. R.; Abessa, D. M. S. (2002), Testes de toxicidade com sedimentos marinhos utilizando anfípodos. In: Métodos em Ecotoxicologia Marinha: Aplicações no Brasil. eds I. A. Nascimento.; E. C. P. M. Sousa and M. G. Nipper. Artes Gráficas e Indústria Ltda. São Paulo. pp. 163-178.

Prósperi, V. A. (2002), Comparação de métodos ecotoxicológicos na avaliação de sedimentos marinhos e estuarinos. Doctorate Thesis. Universidade de São Paulo. Escola de Engenharia de São Carlos. São Carlos. 118p.

Rachid, B. R. F. (2002), Avaliação ecotoxicológica dos efluentes domésticos lançados pelos sistemas de disposição oceânica da Baixada Santista. Doctorate Thesis. Universidade de São Paulo. Instituto Oceanográfico. São Paulo. 286p.
Smith, S. L.; Macdonald, D. D.; Keenleyside, K. A.; Gaudet, C. L. (1996), The development and implementation of Canada Sediment Quality Guidelines. In: Development and Progress in Sediment Quality Assessment: Rationale. Challenges. Techniques and Strategies. eds M. Munawar and G. Dave. SPB Academic Publishing. Amsterdam. The Netherlands. pp.233-249.

U. S. Environmental Protection Agency. (1999), Integrated approach to assessing the bioavailability and toxicity of metals in surface waters and sediments (Including the metals mixtures equilibrium partitioning sediment guideline document). Briefing materials presented to the Science Advisory Board, April 6-7.
Received: January 24, 2006; Revised: May 18, 2007; Accepted: August 11, 2008. 